Media Industries $7.1(2020)$

\title{
Set for Success: Hollywood Runaway Productions in Socialist and Post-socialist Hungary
}

\author{
Omar Sayfo ${ }^{1}$ \\ UTRECHT UNIVERSITY \\ o.a.sayfo [AT] uu.nl
}

\begin{abstract}
In the past decade, Hungary has grown from a peripheral destination of Hollywood runaway productions into the second biggest European filming location. At the same time, after decades of absence from the domestic and international scenes, local productions have made a return, filling national cinemas and winning prestigious international awards. This article investigates the development of Hollywood runaway production in socialist and post-socialist Hungary. On the macro level, it explores how political and economic tendencies, together with individual agents' networks, affected local industries and Hollywood runaway production from the 1960 s to the present. On the micro level, the article looks at Hungarian crew members' self-perceptions and professional identity formation. Doing so, the article strives to reveal the possible links between the two tiers and the effect of wage-work on domestic production.
\end{abstract}

Keywords: Film Industry, Runaway Production, Wage-Work, Hungarian Film, Global Hollywood

Since the mid-1960s, Hungary has been attracting Hollywood runaway productions with authentic locations, favorable exchange rates, low labor costs, and untapped infrastructure. Although the fall of socialism in 1989 heralded a decline of wage-work, the introduction of subsidies and tax rebates in 2004, followed by the reorganization of Hungarian film production in 2011 turned the tide. Budapest, once a minor production center, grew into the second biggest European destination for Hollywood movies, ${ }^{2}$ hosting high-profile productions like Blade Runner 2049 (2017), Dune (2020), and others. At the same time, local productions were also booming, winning around three hundred awards in seven years, including an Academy Award for Son of Saul (2016), a best short film Oscar for Sing (2017), and a Golden Bear for On Body and Soul (2017). 
Hungary is now a major actor in a media landscape that has been defined by the formulation of global production networks and increased international competition among nation-states, cities, and regions. ${ }^{3}$ This also means that there is a division of jobs between a controlling "core" and a low-wage periphery. Hollywood's domination of the world media market lies in its control over the uses and distribution of labor on a global scale and in the coordination of national governments and policies that facilitate the distribution of media labor across international territories. ${ }^{4}$

Despite Hollywood's dominance, American wage-work is not necessarily perceived as exploitation from the destination country's perspective. ${ }^{5}$ Moreover, there has been increased competition to attract high-value creative industries to generate future multiplier effects in local industries. Governments provide incentives such as tax reliefs, waivers of location fees, equity investment, and subsidies in the hope that successful cinematic productions will deliver economic value by attracting business and providing cultural capital through popular identification with a global commodity. ${ }^{6}$

Camille Johnson-Yale showed that Canadian counterdiscourses to runaway film production activate multiple narratives of globalization, including cultural imperialism, pro-globalization, and emancipation. ${ }^{7}$ In his examination of Hollywood runaway productions in the Czech Republic, Petr Szepanik regards the Manchester School of Economic Geography's theory of global production networks (GPNs) of particular relevance. ${ }^{8}$ Similarly, from the perspective of Hungary as a regional post-socialist production center, GPN highlights how local institutions and workers should be considered social actors rather than victims. ${ }^{9}$ In this regard, transnational production is multi-actor and multi-scalar and is embedded in both societal and territorial realities. In a transnational knowledge transfer, knowledge is internalized and translated into capabilities because local suppliers learn by converting explicit into tacit knowledge.

To understand specific cases of industrial discourse, Havens et al. argue that more empirical research on the operation of social power is necessary. ${ }^{10}$ Szczepanik added that while political economists and network theorists offer different assessments of the global relations of motion picture production, they fail to explain how spatially extended webs of productive labor are constituted or how they operate in peripheral production ecologies. ${ }^{11}$ In line with previous observations, this article looks at Hollywood runaway productions from a Hungarian socialist and post-socialist perspective. I will explore how global trends of Hollywood were linked to socialist and post-socialist Hungarian political economic dynamics as well as to local and transnational networks of influence. Moreover, I will connect macro and micro scales of analysis by looking at how it was regarded by local labor. In the following, I will also highlight the role of individual agents and informal networks, which together with local political and economic factors and crews' attitudes were primarily responsible for the unique situation of Hollywood runaway productions in Hungary. To understand Hungarian crew members' attitudes and position, I will explore their identity construction and the social prestige of their profession that contributes to the construction of self-image and collective action. This approach also aims to contribute to the general understanding of the position and self-identification of crew members on the "peripheries" of the globalized Hollywood film industry. 


\section{Domestic Production in Hungary from Socialism to Capitalism}

Hungarian socialist and post-socialist film industry has been a two-tier production system split between international and domestic production. Both of these tiers are characterized by different business models, gatekeepers, career prospects, and levels of precariousness. ${ }^{12}$ Financially, it was a two-pillar system based on indirect state support in the form of tax incentives for films and related projects, and direct state support for local films and coproductions. ${ }^{13}$ Still, domestic film production and wage-work were interlinked by a shared infrastructure and by politics. These frameworks were geared primarily toward domestic production and provided the ground for runaway productions from the 1960s until recently.

When Hungary became part of the Socialist Block in 1945, the local film industry suffered from the preceding emigration of talent, the lack of resources and censorship. ${ }^{14}$ This was especially true in the period that immediately followed the crushing of the anti-Soviet uprising in 1956. However, starting from the early 1960s, under the leadership of Janos Kádár (1956-1988), political consolidation both at home and abroad became a priority. For domestic film production, this meant increased budgets, state support for new actors and directors, and the reorganization of filmmaking. ${ }^{15}$ From 1956 until the collapse of socialism in 1989, state ideologist György Aczél (1917-1991) acted as the ultimate figure in charge of cultural affairs. The Ministry of Culture had the right to censor content, and state-owned Mafilm, as an umbrella film production organization, enjoyed a monopoly on domestic film production. Local productions were in a strong position on the domestic market and were widely distributed in other socialist countries too, and a few even achieved wider international acclaim, for example, István Szabó's Mephisto (1981) which won the award for Best Foreign Language Film at the 54th Academy Awards.

After the fall of socialism in 1989, Mafilm was first broken up into smaller companies and then turned into a joint stock company. In 1991, the supervision of state-funded domestic production was reorganized under the authority of the Hungarian Moving Picture Foundation (HMPF), which was succeeded by the Hungarian Moving Picture Public Fund (HMPPF) in 1998. Made up of some of the most prominent members of socialist-period filmmaking, both HMPF and HMPFF were defined by locally developed management practices, strong networks of patronage, and solid personal links with the University of Theatre and Film Arts in Budapest which was the pool of approximately 70 percent of the above-the-line labor and of actors. ${ }^{16}$

Throughout the 1990s and the early 2000s, with the decrease in state funding, an obsolete studio system, and a flood of foreign film productions, domestic film production decreased, leading to a drop in both the number and quality of productions. The first signs of a possible revival appeared in 2007 when, together with Hungarian and American stakeholders, Hungarian-born American producer Andrew Vajna founded Korda Studios, located in Etyek, outside of Budapest. ${ }^{17}$ Soon, another studio in Mogyoród and a number of smaller studios were established in the Budapest agglomeration, equipped with modern technology and capable of serving even A-category Hollywood productions. ${ }^{18}$ 
In 2010, new opportunities arose for Vajna, when the center-right government led by the Fidesz party came into power. ${ }^{19}$ The new government's declared aim was to revive national cultural production, including film. In 2011, Vajna was nominated Government Commissioner in charge of the Hungarian film industry, and a year later, HMPPF was replaced by the Hungarian National Film Fund (HNFF). ${ }^{20}$

When established, HNFF was fiercely criticized by members of HMPPF and the political opposition because of fears that the center-right government could potentially use the HNFF to create a loyal artistic elite. HNFF's cooperation with the professors of the University of Theatre and Film Arts and the continued funding for renowned directors once affiliated to HMPPF, however, rendered this criticism mute. HNFF was funded by revenues from the National Lottery, making its budget $€ 17$ million, a national record. ${ }^{21}$ Between 2010 and 2014, the government spent 0.15 percent of its gross domestic product (GDP) on film productions, which was double the European average. The funding mechanism introduced in 2011 had the declared aim of bringing Hungarian audiences back to domestic movies, of creating a transparent funding mechanism, and of increasing the prestige of Hungarian film abroad. ${ }^{22}$ In 2015, HNFF's Incubator Program was launched, offering funding for low-budget productions, as well as continuous professional help for directors who wished to make their debut feature films. In 2016, HNFF launched the Film Training Program for below-the-line professions, making every production shoot in Hungary contribute 0.5 percent of its budget to the training program and obligating every project with a budget of more than HUF 10 million to hire trainees for five weeks.

Between the release of the first films supported by the Film Fund in autumn 2013 and 2019, Hungarian productions won approximately three hundred international awards, including Son of Saul's (2015) Golden Globe for Best Foreign Language Film and Best Foreign Language Film Academy Award, and Sing's (2016) Academy Award for Best Live Action Short Film. In 2017, for the first time in decades, Kincsem, a period drama about a famous racehorse, became a national blockbuster.

\section{Hollywood Runaway Productions in Socialist Hungary}

Runaway production emerged in California between 1909 and 1920, driven mainly by geographic realism. After World War II, Hollywood location filming started to increase in postwar Europe as the demise of the studio system in the 1960s made runaway production an attractive option. The mode of production now was a system based on flexible specialization, facilitated by regional networks of production companies and their associated subcontractors.

However, as a general trend, in the late 1960s, runaway productions in Europe started to decline partly owing to concerns over cost-effectiveness and unions' campaign against shooting abroad. Still, producers remained motivated to take productions abroad, in part because of aesthetic concerns over geographic realism and economic concerns over production costs, alongside the producers' wish to escape the rigid rules of the local unions in Los Angeles. In the early 1990s, economic runaways relocated productions to places that had low or no location fees, available studio space, and a skilled "below-the-line" labor pool with 
low costs. ${ }^{23}$ Because of the rapid development of visual technology since the 1990s, runaway production has been less driven by geographic realism than previously.

Hollywood wage-work in Hungary began in the mid-1960s, at a time when runaway to Europe in general started to decline. ${ }^{24}$ Still, low prices, weak unions, the availability of cheap and experienced labor, and geographical realism facilitated a handful of productions to be located in Hungary during the 1960s. Since Hungary was a member of the Eastern block between 1945 and 1989, American wage-work in Hungary can only be understood if set in a wider Cold War framework. Despite political tensions, the first American-Soviet cultural exchange agreement was signed in 1958. By the mid-1960s, the film industries of the United States and the Soviet Union were showing clear signs of the East-West diplomatic thawing that followed the 1962 Cuban missile crisis during the presidency of Lyndon B. Johnson and Richard Nixon. ${ }^{25}$ It was also the time when elements of Hollywood's long-established studio system broke down, opening the way for younger, liberal-minded filmmakers to experiment more boldly on the screen. The 1960s saw numerous attempts to facilitate American-Soviet cinematic coproduction, as Soviet studios coproduced six films with Western partners in the late 1960s and continued to do so in the following decades. ${ }^{26}$

Despite bilateral steps toward normalization, US-Hungarian relations between 1957 and 1967 were as turbulent as world politics in general, with Budapest's freedom of action limited by Soviet domination. ${ }^{27}$ Still, minor steps-such as the US participation in the 1965 International Fair in Budapest-were a clear indication of a shift toward a détente. By the mid-1960s, Hungarian leaders were eager to loosen cultural controls in exchange for Western economic resources. ${ }^{28}$ Therefore, in the early 1960s, Mafilm established its Foreign Department, responsible for the implementation of international coproduction and wage-work. A few years later, another staterun department, Hungarofilm was established to supervise foreign agreements.

The first American-Hungarian project, The Golden Head (1964), was a coproduction between Hunnia Filmstúdió of Mafilm and Metro-Goldwyn-Mayer. As the film's plot takes place in Budapest, Hungarian-British producer Alexander Paal convinced his American partner William R. Forman to choose Hungary as an authentic location. ${ }^{29}$ This production paved the way for the first American wage-work, The Fixer (1968), a drama about corruption, cruelty, and anti-Semitism in Tsarist Russia. ${ }^{30}$ The production was especially welcomed by Hungarian authorities, as director John Frankenheimer was a known critic of the US military's role in politics and the rationality of nuclear deterrence in Seven Days in May (1964). ${ }^{31}$ In the ensuing decade, the trend of geographical realism came as an advantage for Hungary, which frequently doubled for Russia.

The shooting of The Fixer largely coincided with The New Economic Mechanism of 1968, a major economic reform designed by the Hungarian government. ${ }^{32}$ The reform encouraged a cautious economic opening toward the West to gain much-needed hard currency. ${ }^{33}$ As the state encouraged wage-work and Hungary's potential as a destination for runaway productions was endorsed by producers with the necessary experience, foreign wage-work started to pour into the country. ${ }^{34}$ Between 1967 and the collapse of the socialist regime in 1989, approximately thirty Western European and American shootings took place in Hungary, and by the 1970s, wage-work accounted for three-quarters of the export income of Hungarofilm. ${ }^{35}$ The government valued services to Western productions first and foremost in economic 
terms, while on the industry level, Mafilm largely benefited from American partners who regularly left behind advanced technical equipment as part of the payment, which was later used for domestic productions. ${ }^{36}$

While Hungarofilm officially was in charge of attracting projects and publicizing Hungary as a potential location for American productions, Hungarian émigrés continued to play a major role in promoting their country of origin and, also, in bringing their own productions to Hungary. In the 1980s, Andrew G. Vajna became particularly active, starting with Escape to Victory (1981), followed by Hungarian-born photographer Robert Halmi's Phantom of the Opera (1982). One arrangement that represented Hungary's initial economic interlinks with film production was that of The Ninth Configuration (1980), in which case the shooting was located in Hungary because PepsiCo, the film's main sponsor, intended to reinvest the money from the film's production in a Pepsi bottling plant in Hungary. ${ }^{37}$

\section{The Fall and Revival of Wage-Work in Post-socialist Hungary}

Similar to other post-socialist states of the 1990s, the first freely elected government of Hungary was subject to high-level and contradictory pressures. Limited resources combined with immense popular expectations, making the depoliticization of economic decisionmaking virtually impossible. ${ }^{38}$ Therefore, the government's privatization strategy was oriented by the need to repay the country's large external debt to foreign investors. ${ }^{39}$ During the process of privatization, Hungary offered generous incentives for foreign investors, including tax and custom exemptions. Soon, Hungary was fully integrated into global capitalism through debt, trade, foreign direct investment, and banking. ${ }^{40}$

Starting from 1989, Mafilm lost its monopoly over foreign wage-work, opening the field for private limited companies of eligible international networks and capital. Soon, Transatlantic Media Associates (TMA), established in 1988 by John Kemeny, a Hungarian-born Canadian film producer, purchased one-third of Mafilm's stocks and grew into the main company for American wage-work. Simultaneously, two smaller companies, Novafilm and Eurofilm, both run by former associates of Mafilm, also started to operate in Hungary. In the 1990s, another important actor in the field was Robert Halmi International, a production company affiliated to Hallmark Entertainment owned by Robert Halmi, which brought low-budget American productions to Hungary.

A production service firm's primary function is to assist foreign producers in finding the proper locations, facilities, equipment, and crew in the production hubs where they are based, to hire crews, and to ensure that local conditions do not negatively affect a production's costs or schedule. ${ }^{41}$ For producers, Hungarian line producers were seen as cultural mediators and specialists on locations and local crews. They were in charge of managing relationships with producers, colleagues, and assistants, and in some cases also with local residents, business owners, and public servants. ${ }^{42}$ Together with line producers, local production service companies are regarded as cultural mediators between Hollywood and Budapest, as they are responsible for creating Hollywood-style working conditions. Of 
course, low-end American productions have been more willing to travel to distant locations like Hungary than blockbusters defined by large capital and risk.

Soon, wage-work started to decline, as TMA's legal disputes within Mafilm blocked investments into the studio system, and Budapest's regional rival Prague introduced tax refunds for foreign productions, drawing clients away from Hungary. ${ }^{43}$ Nevertheless, despite the declining market, TMA lured some fifty American and Western European productions to Hungary in the ensuing decade, among them Evita (1996), Andrew Vajna's high-profile production. The 2001 dissolution of Mafilm also brought an end to TMA, while Novafilm and Eurofilm went bankrupt, leading to a lack of service companies.

The revival of Hungarian wage-work was driven by economic, human-capital, and management considerations. In 2004, on Andrew Vajna's recommendation, the Hungarian government introduced a 20 percent tax rebate, with the aim of bringing back business from Prague. ${ }^{44}$ In the same year, a new Budapest-based service company, Mid Atlantic Productions, was established by a Briton, Adam Goodman, and an American, Howard Ellis. In 2011, Pioneer Film followed, together with a number of smaller companies with close links to France, Spain, and Scandinavia specializing in costumers from specific countries or domestic production. Geographical proximity to Britain came as an advantage for service providers who mobilized their networks when offering above-the-line labor for their American clients and established a pool of creatives who "travel well" and became accustomed to Hungarian circumstances, labor, and costs. ${ }^{45}$

Budapest, once a minor production center, grew into regional contender in Schiller's "networked global market system," as the tax rebate of 2004 helped attract high-budget movies such as Steven Spielberg's Munich (2005) and Fox's fantasy film Eragon (2006), giving other Hollywood filmmakers the confidence to come to Hungary. ${ }^{46}$

It was not only the tax benefits and lower prices that proved to be attractive. The architecture of Budapest continued to play an important role for many producers, as did the availability of local labor, and developing film infrastructure, like the 2007 establishment of Korda Studio. ${ }^{47}$ This prompt growth is best expressed by official figures. In 2003, a year before the introduction of tax benefits, foreign productions added less than HUF 2 billion to the budget. By 2007, it rose to HUF 25 billion and to HUF 50 billion in 2012. ${ }^{48}$ Since Budapest lured investors away from Prague, foreign film investment fell by 70 percent in the Czech capital. Hungarian wagework gained a momentum in 2011 by hosting the production of a quality TV show, The Borgias. ${ }^{49}$ Soon enough, high-budget productions like World War Z (2013) and Hercules (2014) also chose Budapest over Prague. To bring the country in line with Budapest, the Czech government belatedly implemented a 20 percent cost rebate program in $2010 .{ }^{50}$ In response, the Hungarian government lifted the rebate to 25 percent in 2014 and saw the stream of productions turn into a gush. ${ }^{51}$ In 2018, after a long quarrel with the European Union's European Commission, the Hungarian government raised its production incentive from 25 to 30 percent. $^{52}$

Hollywood productions' demand for modern studios and equipment offered an opportunity for domestic productions to work with state-of-the-art equipment. One case in point is the 2017 opening of ARRI Rental's 2,400-square-meter facility near Budapest, which supplied Blade Runner 2049 (2018) with a full camera, grip, and lighting package. ${ }^{53}$

From the government's point of view, Hollywood wage-work has been mainly seen in economic terms. When assuming power in 2010, the center-right Fidesz government found 
itself under the dual pressure of unrealistic domestic economic expectations, on the one hand, and the external pressure of the European Union and the International Monetary Fund (IMF) for further consolidation of public finances, on the other. ${ }^{54}$ Therefore, Andrew Vajna's promise to transform foreign wage-work into a vital economic field was especially well received by the government. In January 2019, around ten thousand people were directly and indirectly employed by the film industry. In sixteen years, income generated by the industry grew twentyfold. A tax refund of HUF 1,000 (US\$3.4) generates a tax revenue of HUF 1,248 (US\$4.23) and increases the GDP by HUF 3,240 (US\$11). A tax refund of HUF 1 billion (USS3,400,000) facilitates the creation of 555 jobs. ${ }^{5}$ Since the 2012 boom, Hollywood celebrities' encounters in Budapest are widely reported by the national media, and the growing international attention contributes to the ruling right-wing government's domestic discourse that aims to build a narrative that relocates Hungary from its historical semiperipheral position to the center of Europe.

In exchange for these gains, the government has been making significant concessions. According to Miller et al., multinational corporations can potentially have power over the state, as it is reluctant to impose new taxes, constraints, or pro-worker policies in the face of possible declining investment. ${ }^{56}$ Film industries in general, and wage-work in particular, have therefore increased their lobbying power. Still, in many countries, negotiating with local politicians and public authorities has become "especially fraught, given the growing magnitude of the requests from foreign producers and the increasing pressure on representatives to protect historical sites, neighborhoods and residents" as Sanson observed. ${ }^{57}$ However, this only applies moderately to Hungary. As Andrew Vajna noted in an interview, "Bureaucracy is very streamlined. Having been a producer, I know what the issues are and so I try to smooth them out before they happen, and that seems to be working really well." ${ }^{158}$ Insiders of Hungarian wage-work I have interviewed in 2018 regarded Andrew Vajna as a main gatekeeper between the government and the film industry. ${ }^{59}$ As the commissioner's position was subordinated not to a ministry but to the prime minister himself, and developing the film industry was declared a "national interest," Andrew Vajna had a strong political position and high influence on political decision-makers until his death in January 2019. Increasing the value of the incentives was one of the most important goals of his lobbying. ${ }^{60}$ Also, a strong political position was essential to quickly reacting to emerging issues. For example, when the shooting of World War Z in 2013 was interrupted by Hungarian police cracking down on imported fake weapons, representatives lobbied in Parliament to change the law to attract high-budget productions like Die Hard $5{ }^{61}$ Vajna also set up a so-called "one-stop shop system" for renting public spaces as shooting locations, taking the decision out of the local councils' hands when setting the fees for locations in Budapest. To be sure, the Hungarian film industry profited from implementing tax incentives and Andrew Vajna's coziness with the upper political echelons, yet without the local crews who run the industry on a daily basis, the rise of Hungary as an international filming location would have been impossible.

\section{Constructing a Crew Member's Identity}

Production is enhanced when workers share the organization's mission. ${ }^{62}$ Therefore, exploring the aspirations and identity formation of Hungarian crew members is fundamental to 
understand the micro level of Hollywood wage-work in Hungary. While being among the best-paid members of the labor market, Hungarian wage-workers since the 1960 have had little creative autonomy. ${ }^{63}$ For them, geographical mobility has been largely limited to occasions when producers move parts of the shooting to other countries, and upward mobility was only possible within the below-the-line spectrum. Laborers have been also aware of their limitations, for example, they were rarely promoted to heads of departments. ${ }^{64}$ From one production service firm's perspective, Hungarian crew members have to accept that they are not equal to their American or British counterparts, who have more responsibility and more authority. ${ }^{65}$ Indeed, this has been a common experience among Hungarian crew members whom I have interviewed, even if they do not regard themselves as victims of exploitation and are highly motivated to remain in business as long as possible. Of course, crew members' experiences extend across a broad range and could differ from one project to another-mostly depending on size and budget-and also on the personal attitudes of their American and British bosses.

What are possible explanations for Hungarian crews' high level of commitment? Since the 1960s, Hungarian wage-workers have shared a sense of belonging to an exclusive group, defined by working habits and organizational culture which differs from domestic productions. As they see it, they all share the self-discipline to work twelve to sixteen hours a day, often six days a week, cultural understanding, a set of practices compatible with Americans, and sociality. In socialist times, fluency in English was also rare, and it therefore became an integral element of their professional identity.

In this regard, Hungarian wage-workers form what Étienne Wenger described as a "community of practice," a group of people who share an activity, knowledge, and repertoire. Their sense of community is founded on mutual engagement and participation as processes of social learning. ${ }^{66}$ Wenger's typology also describes their cooperation with foreign labor, as it emphasizes negotiation that occurs between communities of practice through joint enterprise and participation in wider "social learning systems."

Although service workers are not technically considered creative employees, "many have come to perceive and represent their work as craft-like, as it has become the marker of status and value throughout the industry." ${ }^{67}$ In this regard, investigating Hungarian wage-labor's identities and motivation, the literature on labor and craft identities is more applicable than that about creative labor. My contention is that establishing a sound professional identity, defined as one's professional self-concept based on attributes, beliefs, values, motives, and experiences, has been crucial for Hungarian crew members. ${ }^{68}$ Such professional identity formation is an on-going process of interpretation and reinterpretation of experiences. ${ }^{69}$ It is not a stable entity; it is complex, personal, and shaped by contextual factors.

Most service firms engage crews on a freelance basis as jobs come in and they prefer to work

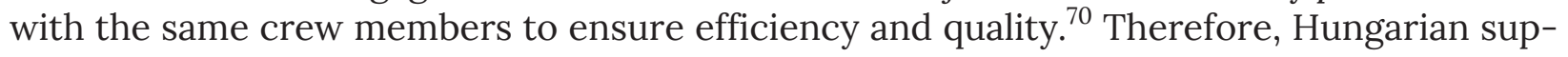
port personnel regard themselves as an exclusive group and form extended informal networks and chains of trust, defined by horizontal flows of information and tacit organizational knowledge. Production managers usually have their own production coordinator, heads of departments have preferred assistants, and assistant directors have their own personal assistants, resulting in protective, often rivaling cliques based on personal trust. 
Sanson noted that as individual crew members of some destination countries for Hollywood runaway productions amass more and more credits on Hollywood productions and develop close relationships with foreign producers and department heads, some might feel overly confident in their job security, ignoring the fact that because of the nature of service work, individuals are assigned as elements of packages of financial, material, and human resources. ${ }^{71}$ Interviewing Hungarian crews, I also found that crew members make every effort to amass more and more credits on Hollywood productions-both in the form of updating personal profiles on IMDb and establishing good working and even personal relations with foreigners. Yet, I also found that the vast majority is well aware of the power relations and dynamics of the industry, and therefore their first and foremost aim to maintain a good profession and personal relationship not with foreigners, but rather with the Hungarian decision-maker who tops their "package."

With the exception of casting agencies recruiting extras, there are no public calls for jobs. ${ }^{72}$ Admission into this exclusive group of support personnel requires personal connections and/or recommendations. During the half-century history of Hungarian wage-work, there have been only two trainee programs, one in 1972/1973 and another in 2016/2017, both responding to an immense labor shortage.

\section{Who Stands Up for Hungarian Wage-Workers?}

Hollywood has a strong tradition of labor activism that dates back to the 1930s, with unions and guilds today representing a wide spectrum of artistic, craft, and industrial employees. ${ }^{73}$ Labor activism has been one of the forces that triggered the waves of runaway productions starting from the 1960s. Toby Miller et al. argue that permissive governments and labor organizations facilitated the extension of studio operations across a vast terrain of regions and locations. Driven by producers' efforts to undermine labor protections and to secure cost advantages, a "new international division of cultural labor" emerged, contributing to the emergence of new production hubs across the globe. ${ }^{74}$ Investigating the relation between the power of unions and runaway production, some observed a growing localism in worker advocacy, loss of collective rights, and a corresponding rise in individualization. ${ }^{75}$

These observations could not be applied in the case of either socialist or post-socialist Hungary. The labor unions of the socialist era (1945-1989) were weak and subordinated to the state, which was also the main employer, hence impossible to challenge. Although the Union of Film Artists and Film Employees (Filmmúvészekés Filmalkalmazottak Szakszervezete) represented thirteen thousand Mafilm workers throughout the 1960s and 1970s, its members did not regard it as a platform for problem solving. ${ }^{76}$ My interviewees who had participated in Hollywood productions during that period agreed that work conditions were barely regulated and were beyond the scope of unions. Some even recall that Hungarian laborers were mostly happy when working on American productions. Despite the frequent overtime, conditions at American shootings were better than at domestic productions, as they offered good catering and extra warm clothes in wintertime. While the fall of socialism in 1989 and the restructuring of the film industry heralded the reorganization of unions, activism in particular, and film labor unions in general, remained marginal. ${ }^{77}$ In the wake of the new 
entrepreneurship regulations, the vast majority of film workers became self-employed by establishing their own small limited companies which signed with the productions, which moved them outside of the scope of unions.

While job security was stable in the socialist era, post-socialist Hungarian support personnel regarded themselves as easily replaceable, especially in the period of decline, and they therefore generally avoided conflicts with foreign above-the-line labor. As a consequence, they were often exploited by some of the local managers and service companies, which were reluctant to pay for overtime and travel compensation, and strove to save money on catering and other expenses. However, my interviewees agreed that support personnel's resentment was targeted not against American producers, but mainly the local Hungarian bosses. Later on, shifting market circumstances largely improved crew members' conditions. By 2016, as the tax rebates continued to attract foreign productions and the HNFF boosted domestic production, a shortage of experienced labor emerged, making film workers more selfconscious, refusing offers of lower salaries, and boycotting those who did not offer suitable work conditions. Also, for the first time, the gap between the wages of crews working on Hollywood productions and those engaged in domestic production narrowed. As a side effect of the labor shortage, foreign and HNFF-funded productions also drew away labor from domestic television production, which resulted in higher labor costs for TV personnel, forcing television producers to save money on nonpersonnel costs such as location and equipment.

\section{The Prestige of Working with Americans}

Hollywood Film industries and the United States in socialist and post-socialist Hungary have enjoyed immense cultural cache. This has influenced not only the professional identity of wage-workers but also their personal identity. Research on professional identity is largely embedded in the study of personal identity, which is defined by Gecas and Burke as "the various meanings attached to oneself by self and others." ${ }^{178}$ In this regard, professional identity is strongly linked to finding one's place in society. Also, belonging to a profession affects one's self-definition and shapes how others think about an individual.

In the 1960s and 1970s, American runaway production in Hungary was little known to the wider public. István Bucsi quoted one of the maxims of the time: "Foreign productions were regarded by many like a family member having a love affair. Everybody knew about it, but was reluctant to talk about it." Also, as Hungarian cinemas were dominated by local productions and imports from other socialist countries, and Hungarian-produced American films were not screened in Hungarian cinemas, there was no marketing value in the media coverage of productions. ${ }^{79}$

Still, working in the film industry in general has been of high social prestige in socialist and post-socialist Hungary, especially participating in Hollywood productions. From the industrial aspect, as foreign productions were bringing much-needed hard currency into the country, they enjoyed privileges to Mafilm's domestic production equipment and studios. ${ }^{80}$ Therefore, members of other departments often envied those working on Hollywood productions, which contributed to the strengthening of their professional cohesion. Socially, 
their prestige partly stemmed from the popular image of the "West" and the United States. Memories of the interwar image of America and of American cultural diplomacy (and propaganda) in the form of radio broadcasts, film, and music undermined the socialist government's anti-American/anti-capitalist propaganda. Therefore, popular opinion glorified the United States, which continued to be seen as the "Promised Land." ${ }^{\prime 1}$ Workers of the domestic film industry also envied their colleagues who worked with American professionals, due to their insight into the professional, financial, and technological advantages of Hollywood industries.

The social prestige of Hungarian crews of American productions experienced a growth by the early 1980s, with the spread of VHS (Video Home System) players and smuggled video tapes of American blockbusters from Western Europe. At that time, the young urban middle-class people became increasingly familiar with Hollywood celebrities like Arnold Schwarzenegger and Sylvester Stallone, and therefore those working on Hollywood productions such as Red Heat (1987) were increasingly envied by nonprofessionals. At the same time, the wider community of film industry workers continued to admire Hollywood film industry for its technological superiority.

After the fall of communism in 1989, Andrew Vajna's InterCom emerged as the market leader and a distributor of many Hollywood studios, including 20th Century Fox, Warner Bros., Sony Pictures, Disney, and MGM both in the cinemas and on VHS. Simultaneously, the introduction of MTV and the general spread of American popular culture pushed the newly established tabloids to celebrate American runaway productions in Hungary. Among others, Michael Jackson's visit for shooting the video clip of History in 1994 and Madonna's arrival for shooting Evita (1996), the first significant production since the collapse of communism, gained wide national attention. As production shoots in Hungary were also presented in national cinemas, coverage of the shootings by the national media and the tabloids now had significant marketing value.

In the 2000s, visiting Hollywood celebrities found themselves more in the focus of media attention. Especially since the 2012 boom, reports of celebrities staying in Budapest are increasingly used for marketing purposes. This attention largely affects crew members' social status, as their-assumed-proximity to celebrities is a source of pride and prestige in the eyes of many outsiders.

\section{Integrating the Worlds of Wage- Work and Domestic Production}

From a socialist and post-socialist Hungarian perspective, Hollywood outsourcing and wagework has not been seen as exploitation. Rather, it was regarded as an economic opportunity by the government, an economic and technological advance by the industry, and a means of personal fulfillment, the construction of a professional identity and good income by the workers.

As we have seen, socialist Hungary's film production was a two-tier system, divided between domestic production and wage-work, which were connected by loose institutional ties only. The revival in the 2000s after the collapse of both tiers following the fall of socialism led to a 
partial, but nevertheless significant integration of domestic production and wage-work, making the latter boost the former.

As a general rule, foreign wage-work does not necessarily affect domestic production. In the Czech Republic, for example, policy-makers' expectations that knowledge transfer, sharing a labor pool and infrastructure, as well as interaction, observation, and imitation would lead incoming producers to gradually transform the practices and styles of the domestic industry did not materialize, as overseas producers had little interest in reshaping local production by hiring local above-the-line talent or hiring Czechs as department heads. ${ }^{82}$ Therefore, the Hungarian experience is unique, at least in Europe.

While foreign and domestic production are still financially separated, the 2011 establishment of HNFF led to the integration of the two distinct worlds into one in infrastructure, regulation, and, also, labor pool. ${ }^{83}$ HNFF financial funds, together with the experience of belowthe-line labor, enabled Hungarian above-the-line labor to create conditions resembling Hollywood productions. The producers of home-grown Academy Award-winning films Son of Saul and Sing as well as creators of national blockbusters largely benefited from modern studios, available high-end equipment, and the pool of below-the-line labor that had gained sufficient experience by working on Hollywood productions.

What makes the Hungarian case unique is the outsized role of singular agents at the center of informal networks acting in small, informal economies. It was not only institutions but also individuals who facilitated deals and industry-level transformations during and since socialism. In this process, local political ambitions and industrial actors' informal links with politics, alongside their power of lobbying, were equally important elements. Therefore, the death of the number one agent, Andrew Vajna in January 2019, is a major loss to Hungarian film industries, with a yet uncertain effect on Hungarian wage-work. Participants now can only hope that the system Vajna has created is stable enough to stand on its own feet.

${ }^{1}$ Omar Sayfo is a researcher of Hungarian-Syrian background at Utrecht University. In 2014, he was a visiting scholar at the Centre of Islamic Studies at the University of Cambridge. His main research field is media and political propaganda. He is also an author of a number of popular articles published among many others in The New York Times, Huffington Post, and Foreign Policy.

${ }^{2}$ The largest European host of Hollywood runaway productions is London.

${ }^{3}$ Toby Miller, Richard Maxwell, John McMurria, Nitin Govil, and Tino Wang, Global Hollywood 2 (London: British Film Institute, 2005).

${ }^{4}$ Michael Curtin and Kevin Sanson, Voices of Labor: Creativity, Craft, and Conflict in Global Hollywood (Oakland: University of California Press, 2017), 1.

${ }^{5}$ Taking a Hungarian perspective, this article prefers the term "wage-work" (bérmunka) as my Hungarian interviewees and sources also prefer the term, both when referring to state-socialist and post-socialist periods, regardless of different employment and contractual practices.

${ }^{6}$ Michael A. Keane, "Once Were Peripheral: Creating Media Capacity in East Asia," Media Culture and Society 28 (6, 2006): 835-55. 
${ }^{7}$ Camille Johnson-Yale, "So-called Runaway Film Production": Countering Hollywood's Outsourcing Narrative in the Canadian Press," Critical Studies in Media Communication 25 (2, 2008): 113-34.

${ }^{8}$ Petr Szczepanik, "Transnational Crews and Post-socialist Precarity: Globalizing Screen Media Labor in Prague," in Precarious Creativity: Global Media, Local Labor, ed. Michael Curtin and Kevin Sanson (Oakland: University of California Press, 2016), 88-90.

${ }^{9}$ Neil M. Coe, Peter Dicken, and MartinHess, "Global Production Networks: Realizing the Potential," Journal of Economic Geography 8 (2008): 271-95; Neil M. Coe and Jennifer Johns, "Beyond Production Clusters: Towards a Critical Political Economy of Networks in the Film and Television Industries," in The Cultural Industries and the Production of Culture, ed. Dominic Power and Allen J. Scott (London: Routledge, 2004), 188-204; Terry Flew, Understanding Global Media (NY: Palgrave Macmillan, 2007).

10 Timothy Havens, Amanda D. Lotz, and Serra Tinic, "Critical Media Industry Studies: A Research Approach," Communication, Culture \& Critique 2 (2, 2009): 249.

${ }^{11}$ Szczepanik, "Transnational Crews," 88.

${ }^{12}$ Television film productions could be considered as a third tier, which is beyond the scope of this article.

13 "The Hungarian Tax Credit System and the 20\% Rebate Scheme," Studies in Eastern European Cinema 1 (1, 2010): 127-30.

${ }^{14}$ Gyöngyi Balogh, Vera Gyürey, and Pál Honffy, A magyar játékfilm története a kezdetektől 1990-ig. (Budapest: Múszaki könyvkiadó, 2004), 69.

${ }^{15}$ John Cunningham, Hungarian Cinema: From Coffee House to Multiplex (NY: Wallflower Press, 2004), 94-97.

${ }^{16}$ Telephone interview with Gábor Balázs, Head of the Film and Media Department at the University of Theatre and Film Arts, August 6, 2019.

${ }^{17}$ The main shareholders in the studio were Andrew Vajna, Nathaniel Philip Rotschild, Peter Munk, and Sándor Demján.

${ }^{18}$ Mónika Kun, "Etyekwood után itt a 'Mogyiwood'," Origo, March 1, 2008. http:// www.origo.hu/gazdasag/hirek/20080228-mogyorod-is-bekapcsolodik-akulfoldi-filmkeszitesbe.html (accessed December 5, 2018).

${ }^{19}$ Gergely Brückner, "Nem lesz egyszerú kibogozni a Vajna-örökséget," Index, January 21, 2019, https://index.hu/gazdasag/2019/01/21/kie_lesz_a_vajna-vagyon/ (accessed January 28, 2019).

${ }^{20}$ The Hungarian National Film Fund is a public institution governed by Hungarian law, and its activities are regulated according to the Motion Picture Act (II) of 2004. See MMKA, "Tájékoztató a Magyar Mozgókép Közalapítvány megszüntetéséről," March 27, 2012, https://web.archive.org/web/20130517194141/http://www.mmka.hu/ kozlemenyek/tajekoztato-a-magyar-mozgokep-kozalapitvany-megszunteteserol (accessed December 10, 2018).

${ }^{21}$ Balázs Varga, "Tradition and Modernization. Contemporary Hungarian Popular Cinema," Images 12 (22, 2013), https://pressto.amu.edu.pl/index.php/i/article/ view/3539 (accessed December 10, 2018). 
${ }^{22}$ MTI, "Megújul a filmtámogatási rendszer, létrejön a Magyar Nemzeti Filmalap," MTI, May 2, 2011, https://www.feol.hu/belfold/megujul-a-filmtamogatasi-rendszerletrejon-a-magyar-nemzeti-filmalap-1136156/ (accessed December 12, 2018).

${ }^{23}$ For the history of Hollywood runaway productions, see, among many others: Chris Lukinbeal, "Runaway Hollywood: Cold Mountain, Romania," Erdkunde 60 (4, 2006): 337-45; Daniel Steinhart, Runaway Hollywood: Internationalizing Postwar Production and Location Shooting (Oakland: University of California Press, 2019); Greg Elmer and Mike Gasher, Contracting Out Hollywood: Runaway Productions and Foreign Location Shooting (Oxford: Rowman \& Littlefield, 2005).

${ }^{24}$ Daniel Steinhart, Runaway Hollywood: Internationalizing Postwar Production and Location Shooting (Oakland: University of California Press, 2019), 6.

${ }^{25}$ László Borhi, Dealing with Dictators: The United States, Hungary, and East Central Europe, 1942-1989 (Bloomington: Indiana University Press, 2016).

${ }^{26}$ Paula Michaels, "Mikhail Kalatozov's The Red Tent: A Case Study in International Co-production across the Iron Curtain," Historical Journal of Film, Radio and Television 26 (3, 2006): 311-26; Marsha Siefert, "Co-producing Cold War Culture: East-West Film-making and Cultural Diplomacy," in Divided Dreamworlds? The Cultural Cold War East and West, ed. Peter Romijn, Giles Scott-Smith, and Joes Segal (Amsterdam: Amsterdam University Press, 2012), 73-94; Donald Richie, The Films of Akira Kurosawa (Berkeley: University of California Press, 1999), 195-203.

${ }^{27}$ László Borhi, "We Hungarian Communists Are Realists': János Kádár's Foreign Policy in the Light of Hungarian-US Relations, 1957-67," Cold War History 4 (2, 2004): 1-32.

${ }^{28}$ Borhi, Dealing with Dictators, 197.

${ }^{29}$ Cunningham, Hungarian Cinema, 97.

${ }^{30}$ Clara Reece, a Romanian-born business executive, was one of the principal negotiators of business deals between the United States and the Soviet Union in the 1960s and 1970s. Reece acted as a go-between for Metro-Goldwyn-Mayer and the Hungarian authorities on The Fixer. See Tony Shaw, "Nightmare on Nevsky Prospekt: The Blue Bird as a Curious Instance of US-Soviet Film Collaboration during the Cold War," Journal of Cold War Studies 14 (1, 2012): 11.

${ }^{31}$ Michael Coyne, "Seven Days in May: History, Prophecy and Propaganda," in Windows on the Sixties: Exploring Key Texts of Media and Culture, ed. Anthony Aldgate, James Chapman, and Arthur Marwick (London: I.B. Tauris, 2000), 70-90.

${ }^{32}$ David Granick, "The Hungarian Economic Reform," World Politics 25 (3, 1973) 414-29.

${ }^{33}$ Attila Mong, Kádár hitele. A magyar államadósság története 1956-1990 (Budapest: Libri, 2012).

${ }^{34}$ In reconstructing the yet unwritten history of Hollywood runaway production in the socialist era, I largely relied on interviews I conducted in Budapest between December 1 and 7, 2018, with the following former crew members: Dezsó Jutasi (1967-1975), Ildikó Végvári (1975-1987), István Bucsi (1964-1986), and Mária Ungor (1972-1992).

${ }^{35}$ Lia Somogyi, "A Hungarofilm története (1956-2001)," Filmkultúra, 2005, https:/ /filmkultura.hu/regi/2005/articles/essays/hungarofilm.hu.html (accessed December 8, 2018). 
${ }^{36}$ This information was confirmed by all four above-mentioned crew members active in the socialist-era.

${ }^{37}$ Bob McCabe, The Exorcist: Out of the Shadows (London: Omnibus Press, 1999), 168.

${ }^{38}$ Roderick Martin, "Post-socialist Segmented Capitalism: The Case of Hungary. Developing Business Systems Theory," Human Relations 61 (1, 2008): 131-59.

${ }^{39}$ Jan Drahokoupil, Globalization and the State in Central and Eastern Europe: The Politics of Foreign Direct Investment (London: Routledge, 2008), 179.

${ }^{40}$ Drahokoupil, Globalization and the State, 41-46.

${ }^{41}$ Kevin Sanson, "Stitching it all Together: Service Producers and the Spatial Dynamics of Screen Media Labor," International Journal of Cultural Studies 21 (4, 2018): 359-74.

${ }^{42}$ Michael Curtin and Kevin Sanson, "Listening to Labor," in Voices of Labor: Creativity, Craft, and Conflict in Global Hollywood, ed. Michael Curtin and Kevin Sanson (Oakland: University of California Press, 2017), 1-17.

${ }^{43}$ Piac és Profit, "Bérmunkátlanság," Piac és Profit, March 27, 2002, https:// piacesprofit.hu/gazdasag/bermunkatlansag/ (accessed December 12, 2018); Napi, “Az ÁPV Rt. kivásárolná a TMA-t a Mafilmből," Napi, November 30, 1999. https://www.napi.hu/belfold_vallalatok/az_apv_rt_kivasarolna_a_tma-t_a_ mafilmbol.16087.html (accessed December 12, 2018).

44 "The Hungarian Tax Credit System."

${ }^{45}$ Among others, Budapest doubled for Atlantic City, Beijing, Berlin, Buenos Aires, Florence, Kiev, London, Madrid, Monte Carlo, Moscow, Munich, New York, Paris, Prague, Rome, Saint Petersburg, Stockholm, Vienna, and Washington.

${ }^{46}$ See Dan Schiller, Digital Capitalism: Networking the Global Market System (Cambridge, MA: MIT Press, 1999).

${ }^{47}$ Leo Barraclough, "Hungary's Tax Incentives, Skilled Workers and Low Costs Lure World Filmmakers," Variety, November 2, 2017, https://variety.com/2017/ artisans /spotlight/atomic-blonde-blade-runner-2049-1202605003-1202605003/ (accessed December 12, 2018).

48 Ádám Bihari, "Bruce Willis segít Matolcsynak," 24.hu, May 11, 2012, https://24 .hu/kultura/2012/05/11/igy-segit-bruce-willis-matolcsy-gyorgynek/ (accessed December 14, 2018).

${ }^{49}$ Anikó Imre, "Introduction: Eastern European Cinema from No End to the End (as We Know It)," In A Companion to Eastern European Cinemas, ed. Anikó Imre (Malden, MA: Wiley \& Sons, 2011), 1-3.

${ }^{50}$ Szczepanik, "Transnational Crews," 93.

51 The value of movie production in Hungary more than tripled from US\$120 million in 2011 to in excess of US\$400 million in 2017. See Bihari, "Bruce Willis segit Matolcsynak."

${ }^{52}$ Barraclough, "Hungary's Tax Incentives."

${ }^{53}$ Ibid.

${ }^{54}$ István Benczes, "From Goulash Communism to Goulash Populism: The Unwanted Legacy of Hungarian Reform Socialism," Post-Communist Economies 28 (2, 2016): 157.

55 The analysis commissioned by HNFF was conducted by OrienTax. See Megéri hollywoodi produkciókat az országba csábítani, February 7, 2017, https://mnf.hu/ 
hu/filmipar/magyarorszagnak-megeri-hollywoodi-produkciokat-az-orszagbacsabitani (accessed December 14, 2018).

${ }^{56}$ Miller et al., Global Hollywood 2, 52.

${ }^{57}$ Sanson, "Stitching it all Together."

${ }^{58}$ Barraclough, "Hungary's Tax Incentives."

${ }^{59}$ When investigating labor, I conducted sixteen interviews in November and December 2018 with second assistant directors, personal assistants, dressers, and so on, currently active in wage-work.

${ }^{60}$ Michael Curtin and Kevin Sanson, "Adam Goodman, Service Producer," in Voices of Labor: Creativity, Craft, and Conflict in Global Hollywood, ed. Michael Curtin and Kevin Sanson (Oakland: University of California Press, 2017), 159.

${ }^{61}$ Ibid., 167.

${ }^{62}$ Canice Prendergast, "The Motivation and Bias of Bureaucrats," American Economic Review 97 (1, 2007): 180-96. Timothy Besley and Maitreesh Ghatak, "Competition and Incentives with Motivated Agents," American Economic Review 95 (3, 2005): 616-36.

${ }^{63}$ From the 1960s until the fall of communism in 1989, Hungarian below-the-line labor working on foreign productions received the same monthly wage as their colleagues working on domestic production. However, receiving an additional daily wage from the film's budget often meant a 30 to 50 percent increase in their salaries.

${ }^{64}$ After 2004, at least in the case of small-scale productions, it became increasingly common for Hollywood productions to hire a Hungarian creative on the side of the American or British heads of department, who is mainly in charge in organizing the Hungarian department members' work.

${ }^{65}$ Curtin and Sanson, "Adam Goodman," 163.

${ }^{66}$ Etienne Wenger, "How We Learn. Communities of Practice. The Social Fabric of a Learning Organization," The Healthcare Forum Journal 39 (4, 1996): 20-26; Jean Lave and Etienne Wenger, Situated Learning: Legitimate Peripheral Participation (Cambridge: Cambridge University Press, 1991).

${ }^{67}$ Curtin and Sanson, "Listening to Labor," 5.

${ }^{68}$ Hermina Ibarra, "Provisional Selves: Experimenting with Image and Identity in Professional Adaptation," Administrative Science Quarterly 44 (4, 1999): 764-91.

${ }^{69}$ Douwe Beijaard, Paulien C. Meijer, and Nico Verloop, "Reconsidering Research on Teachers' Professional Identity," Teaching and Teacher Education 20 (2, 2004):10728; David V. Day, William E. Cross Jr., Erika L. Ringseis, and Tamara L. Williams, "Selfcategorization and Identity Construction Associated with Managing Diversity," Journal of Vocational Behavior 54 (1, 1999): 188-95; Anthony Paul Kerby, Narrative and the Self, (Bloomington: Indiana University Press, 1991).

${ }^{70}$ Sanson, "Stitching it all Together," 359-74.

${ }^{71}$ Sanson, "Stitching it all Together," 373.

${ }^{72}$ Melitta Kotroczó, "Ebben a szakmában a gyakornokok is 20 ezret visznek haza naponta," Pénzcentrum, December 30, 2017, https://www.penzcentrum .hu/karrier/ebben-a-szakmaban-a-gyakornokok-is-20-ezret-visznek-haza -naponta.1062593.html (accessed December 13, 2018). 
${ }^{73}$ See David F. Prindle, The Politics of Glamor: Ideology and Democracy in the Screen Actors Guild (Madison: University of Wisconsin Press, 1988); Gerald Horne, Class Struggle in Hollywood: Moguls, Mobsters, Stars, Reds, and Trade Unionists, 1930-1950 (Austin: University of Texas Press, 2001); Denise Hartsough, "Film Union Meets Television: IA Organizing Efforts, 1947-1952," Labor History 33 (3, 1992): 357-71.

${ }^{74}$ Miller et al., Global Hollywood 2, 9-10.

${ }^{75}$ Susan Christopherson, "Divide and Conquer: Regional Competition in a Concentrated Media Industry," in Contracting Out Hollywood: Runaway Productions and Foreign Location Shooting, ed. Greg Elmer and Mike Gasher (NY: Rowman \& Littlefield, 2005), 38; David Hesmondhalgh and Sarah Baker, "Toward a Political Economy of Labor in the Media Industries," in The Handbook of Political Economy of Communications, ed. Janet Wasko, Graham Murdock, and Helena Sousa (Malden, MA: Blackwell, 2011), 225.

${ }^{76}$ Interview with Károly Duló, president of the Union of Film Artists and Film Employees, Budapest, December 4, 2018.

${ }^{77}$ Michael Curtin and Kevin Sanson, Precarious Creativity Global Media, Local Labor (Oakland: University of California Press, 2016), 3.

${ }^{78}$ Viktor Gecas and Peter J. Burke, "Self and Identity," in Sociological Perspectives on Social Psychology, ed. Karen S Cook, Gary Alan Fine, and James S. House (Boston, MA: Allyn \& Bacon, 1995), 42.

79 The number of American movies screened in Hungarian cinemas between 1960 and 1965 was between 5 and 10, growing to 10-15 in the late 1960s and 18-20 in the early 1970s. American import was dominated by products of the New York school, while relatively few Hollywood productions reached the screens. See: Róbert Takács, "A nyugati film és közönsége Magyarországon Sztálin halálától Helsinkiig (1953-1975)," Korall Társadalomtörténeti Folyóirat 17 (65, 2016): 137-63.

${ }^{80}$ Attila Mong, Kádár hitele-A magyar államadósság története 1956-1990 (Budapest: Libri, 2012).

81 Tibor Glant, "Travel Writing as a Substitute for American Studies in Hungary," Hungarian Journal of English and American Studies 16 (1-2, 2010): 181.

${ }^{82}$ Szczepanik, "Transnational Crews," 96.

${ }^{83}$ Speaking about labor, Hungarian National Film Fund (HNFF) closed the labor culture and network gap between international and domestic film production, but widened the gap between domestic production and television production.

\section{Bibliography}

Beijaard, Douwe, Paulien C. Meijer, and Nico Verloop. "Reconsidering Research on Teachers' Professional Identity," Teaching and Teacher Education 20, no. 2 (2004): 107-28.

Besley, Timothy, and Maitreesh Ghatak. "Competition and Incentives with Motivated Agents," American Economic Review 95, no. 3 (2005): 616-36.

Benczes, István. "From Goulash Communism to Goulash Populism: The Unwanted Legacy of Hungarian Reform Socialism." Post-Communist Economies 28, no. 2 (2016): 146-66.

Borhi, László. “We Hungarian Communists Are Realists’: János Kádár's Foreign Policy in the Light of Hungarian-US Relations, 1957-67," Cold War History 4, no. 2 (2004): 1-32. 
Borhi, László. Dealing with Dictators: The United States, Hungary, and East Central Europe, 1942-1989. Bloomington: Indiana University Press, 2016.

Christopherson, Susan. "Divide and Conquer: Regional Competition in a Concentrated Media Industry." In Contracting Out Hollywood: Runaway Productions and Foreign Location Shooting, edited by Greg Elmer and Mike Gasher, 21-40. New York: Rowman \& Littlefield, 2005.

Coyne, Michael. "Seven Days in May: History, Prophecy and Propaganda." In Windows on the Sixties: Exploring Key Texts of Media and Culture, edited by Anthony Aldgate, James Chapman, and Arthur Marwick, 70-90. London: I.B. Tauris, 2000.

Cunningham, John. Hungarian Cinema: From Coffee House to Multiplex. New York: Wallflower Press, 2004.

Curtin, Michael, and Kevin Sanson. Precarious Creativity Global Media, Local Labor. Oakland: University of California Press, 2016.

Curtin, Michael, and Kevin Sanson. "Adam Goodman, Service Producer." In Voices of Labor: Creativity, Craft, and Conflict in Global Hollywood, edited by Michael Curtin and Kevin Sanson, 158-68. Oakland: University of California Press, 2017.

Curtin, Michael and Kevin Sanson. "Listening to Labor." In Voices of Labor: Creativity, Craft, and Conflict in Global Hollywood, edited by Michael Curtin and Kevin Sanson, 1-17. Oakland: University of California Press, 2017.

Day, David V., William E. Cross Jr., Erika L. Ringseis, and Tamara L. Williams. "SelfCategorization and Identity Construction Associated with Managing Diversity." Journal of Vocational Behavior 54, no. 1. (1999): 188-95.

Drahokoupil, Jan. Globalization and the State in Central and Eastern Europe: The Politics of Foreign Direct Investment. London: Routledge, 2008.

Elmer, Greg, and Mike Gasher. Contracting out Hollywood: Runaway Productions and Foreign Location Shooting. Oxford: Rowman \& Littlefield, 2005.

Flew, Terry. Understanding Global Media. New York: Palgrave Macmillan, 2007.

Gecas, Viktor, and Peter J. Burke. "Self and Identity." In Sociological Perspectives on Social Psychology, edited by Karen S Cook, Gary Alan Fine, and James S. House, 41-67. Boston, MA: Allyn \& Bacon, 1995.

Glant, Tibor. "Travel Writing as a Substitute for American Studies in Hungary." Hungarian Journal of English and American Studies 16, no. 1-2 (2010): 171-84.

Granick, David. "The Hungarian Economic Reform." World Politics 25, no. 3 (1973): 414-29.

Gyöngyi, Balogh, Gyürey Vera, and Honffy Pál. A magyar játékfilm története a kezdetektől 1990-ig. Budapest: Múszaki könyvkiadó, 2004.

Hartsough, Denise. "Film Union Meets Television: IA Organizing Efforts, 1947-1952." Labor History 33, no. 3 (1992): 357-71.

Havens, Timothy, Amanda D. Lotz, and Serra Tinic. "Critical Media Industry Studies: A Research Approach." Communication, Culture \& Critique 2, no. 2 (2009): 234-53. 
Hesmondhalgh, David, and Sarah Baker. "Toward A Political Economy of Labor in the Media Industries." In The Handbook of Political Economy of Communications, edited by Janet Wasko, Graham Murdock and Helena Sousa, 381-400. Malden, MA: Blackwell, 2011.

Horne, Gerald. Class Struggle in Hollywood: Moguls, Mobsters, Stars, Reds, and Trade Unionists 1930-1950. Austin: University of Texas Press, 2001.

Imre, Anikó. "Introduction: Eastern European Cinema from No End to the End (as We Know It)." In A Companion to Eastern European Cinemas, edited by Anikó Imre, 1-22. Malden, MA: Wiley \& Sons, 2011.

Johnson-Yale, Camille. "'So-called Runaway Film Production': Countering Hollywood's Outsourcing Narrative in the Canadian Press." Critical Studies in Media Communication 25, no. 2 (2008): 113-34.

Kerby, Anthony Paul. Narrative and the Self. Bloomington: Indiana University Press, 1991.

Lave, Jean, and Etienne Wenger. Situated Learning: Legitimate Peripheral Participation. Cambridge: Cambridge University Press, 1991.

Lukinbeal, Chris. "Runaway Hollywood: Cold Mountain, Romania." Erdkunde 60, no. 4 (2006): $337-45$.

Martin, Roderick. "Post-socialist Segmented Capitalism: The Case of Hungary. Developing Business Systems Theory." Human Relations 61, no. 1 (2008): 131-59.

McCabe, Bob. The Exorcist: Out of the Shadows. London: Omnibus Press, 1999.

M.Coe, Neil, Peter Dicken, and Martin Hess. "Global Production Networks: Realizing the Potential." Journal of Economic Geography 8 (2008): 271-95.

M. Coe, Neil, and Jennifer Johns. "Beyond Production Clusters: Towards a Critical Political Economy of Networks in the Film and Television Industries." In The Cultural Industries and the Production of Culture, edited by Dominic Power and Allen J. Scott, 188-204. London: Routledge, 2004.

Michaels, Paula. "Mikhail Kalatozov's The Red Tent: A Case Study in International Co-production across the Iron Curtain." Historical Journal of Film, Radio and Television 26, no. 3 (2006): 311-26.

Miller, Toby. "The New International Division of Cultural Labor Revisited." Journal of Communication and Emergent Technologies 14, no. 2 (2016): 97-121.

Mong, Attila. Kádár hitele-A magyar államadósság története 1956-1990. Budapest: Libri, 2012.

Prendergast, Canice. "The Motivation and Bias of Bureaucrats." American Economic Review 97, no. 1 (2007): 180-96.

Prindle, David F. The Politics of Glamour: Ideology and Democracy in the Screen Actors Guild. Madison: University of Wisconsin Press, 1988.

Richie, Donald. The Films of Akira Kurosawa. Berkeley: University of California Press, 1999.

Sanson, Kevin. "Stitching it all Together: Service Producers and the Spatial Dynamics of Screen Media Labor." International Journal of Cultural Studies 21, no. 4 (2018): 359-74. 
Schiller, Dan. Digital Capitalism: Networking the Global Market System. Cambridge, MA: MIT Press, 1999.

Shaw, Tony. "Nightmare on Nevsky Prospekt: The Blue Bird as a Curious Instance of US-Soviet Film Collaboration during the Cold War." Journal of Cold War Studies 14, no. 1(2012): 3-33.

Siefert, Marsha. "Co-producing Cold War Culture: East-West Film-making and Cultural Diplomacy." In Divided Dreamworlds? The Cultural Cold War East and West, edited by Peter Romijn, Giles Scott-Smith, and Joes Segal, 73-94. Amsterdam: Amsterdam University Press, 2012.

Steinhart, Daniel. Runaway Hollywood: Internationalizing Postwar Production and Location Shooting. Oakland: University of California Press, 2019.

Szczepanik, Petr. "Transnational Crews and Post-socialist Precarity: Globalizing Screen Media Labor in Prague." In Precarious Creativity: Global Media, Local Labor, edited by Michael Curtin and Kevin Sanson, 88-103. Oakland: University of California Press, 2016.

"The Hungarian Tax Credit System and the 20\% Rebate Scheme." Studies in Eastern European Cinema 1, no. 1 (2010): 127-30.

Varga, Balázs. "Tradition and Modernization. Contemporary Hungarian Popular Cinema." Images 12, no. 22 (2013). https://pressto.amu.edu.pl/index.php/i/article/view/3539.

Wenger, Etienne. "How We Learn. Communities of Practice. The Social Fabric of a Learning Organization." The Healthcare Forum Journal 39, no. 4 (1996): 20-26. 
